\title{
Changes in flavour and texture during the ripening of strawberries
}

\section{Journal Article}

\section{Author(s):}

Azodanlou, Ramin; Darbellay, Charly; Luisier, Jean-Luc; Villettaz, Jean-Claude; Amadò, Renato

Publication date:

2004-01

Permanent link:

https://doi.org/10.3929/ethz-b-000052058

Rights / license:

In Copyright - Non-Commercial Use Permitted

Originally published in:

European Food Research and Technology 218(2), https://doi.org/10.1007/s00217-003-0822-0 


\author{
Ramin Azodanlou - Charly Darbellay • \\ Jean-Luc Luisier • Jean-Claude Villettaz • \\ Renato Amadò
}

\title{
Changes in flavour and texture during the ripening of strawberries
}

Received: 17 June 2003 / Published online: 26 November 2003

(C) Springer-Verlag 2003

\begin{abstract}
The amount of total volatile compounds, total acidity, total sugar content (degrees Brix) and fruit firmness were used to characterize the degree of ripeness of three strawberry varieties (Carezza, Darselect and Marmolada). A novel concept using solid phase microextraction (SPME) and measurement of total volatile compounds to distinguish between various stages of strawberry ripeness was applied. The carboxene/polydimethylsiloxane SPME fibre was found to be best suited to differentiate between the stages of ripeness. The amount of total volatile compounds rapidly increased near to maturity (between the three-quarters red stage and the dark-red stage). Most of the volatile compounds identified were esters, followed by aldehydes, and alcohols. The most abundant volatile compounds were propyl butanoate, 3-phenyl-1-propanol, butyl butanoate, isobutyl butanoate, 3-methyl butyl butanoate and isopropyl hexanoate. The concentration of green aroma components such as hexanal, trans-2-hexenol and cis-3hexenyl acetate progressively decreased during the maturation process until they became minor components in mature strawberries.
\end{abstract}

R. Azodanlou · R. Amadò ( $\bullet$ )

Swiss Federal Institute for Technology of Zurich,

Institute for Food Science and Nutrition,

ETH Zentrum,

Schmelzbergstrasse 9, CH-8092 Zurich, Switzerland

e-mail: renato.amado@ilw.agrl.ethz.ch

Tel.: +41-1-632-3291

Fax: +41-1-632-1123

C. Darbellay

Swiss Federal Research Station for Plant Production,

CH-1964 Conthey, Switzerland

\section{J.-L. Luisier · J.-C. Villettaz}

Department of Food Technology and Biotechnology,

Ecole d' Ingénieurs du Valais,

CH-1950 Sion, Switzerland

Present address:

R. Azodanlou, Syngenta Biotechnology Inc.,

3054 Cornwallis Rd., Research Triangle Park, P.O. Box 12257,

NC 27709-2257, USA
Keywords Ripeness - Total volatile $\cdot$ Solid phase microextraction - Strawberry $\cdot$ Flavour $\cdot$ Texture

\section{Introduction}

The quality of strawberries is defined by sensory attributes such as flavour and texture. Plant selection, growing conditions (soil, climate, etc.), harvest date, and post-harvest treatments all influence these quality attributes [1].

Fruit ripening is a very complex process. It is influenced by the synthesis and action of hormones responsible for the rate of ripening, the biosynthesis of pigments (carotenoids, anthocyanins, etc.), the metabolism of sugars, acids and volatile compounds involved in flavour development. In addition the modifications of the structure and composition of the cell wall are known to affect the texture of the fruit $[2,3]$.

Glucose, fructose and sucrose are by far the most abundant soluble components in strawberries. The sugars constitute precursors of flavour compounds (e.g. furanones), and are primarily used as an energy source in the ripening process [4]. Acids can affect flavour as well, but they are more important in processing [5]. Further, it has been shown that volatile fatty acids play an important role in ester formation in strawberries [6].

A small number of researchers have focused their work on changes in the profile of volatile compounds during fruit ripening $[6,7,8,9,10]$. During the ripening process the capacity to esterify 1-pentanol is developed by the fruit, presumably by enzymatic reactions, although the enzymes responsible have not yet been characterized [6]. Alternatively, some flavour components could be the products of non-enzymatic reactions (e.g. the reaction of an alcohol with an acid), where the formation of precursors is enzymatically controlled. The authors Yamashita et al. pointed out that esters and furanones are key compounds of the strawberry flavour. An increase in the total amount of volatile compounds during ripening has also been observed [7]. Esters, in particular large amounts 
of methyl acetate and methyl butanoate, were predominant. The concentration of volatile compounds increased during ripening of Chandler strawberries, and ethyl hexanoate, ethyl butanoate and methyl butanoate were the predominant components present in the fully ripe fruit [8]. The relationship between the degree of maturity and the concentration of 2,5-dimethyl-4-hydroxy-3(2H)-furanone and its derivatives has been investigated in seven strawberry varieties by Sanz et al. [9].

The influence of sampling on flavour analysis was discussed by Parliament, who stated that liquid-liquid extraction and simultaneous distillation may lead to the production of artefacts, whereas solid phase microextraction (SPME) allowed a more reliable flavour analysis [10].

In the present study a quantitative analysis of flavour compounds and an assessment of texture changes during strawberry ripening were carried out. Three strawberry varieties were investigated. Flavour analysis was performed after SPME, measurement of total volatile compounds, GC-FID and GC-MS. For each strawberry variety the chromatographic aroma profiles at six different ripening stages were compared. The results were processed by principal component analysis (PCA). Total acidity, total sugar content (degrees Brix) and fruit firmness (using a Kramer shear cell) were determined as well.

\section{Materials and methods}

Fruit samples and sample preparation

Three commercial varieties of strawberries (Carezza, Darselect and Marmolada) grown under plastic tunnels were obtained from the Swiss Federal Research Station for plant production in Conthey (Switzerland). The fruits were harvested at six different ripening stages (green, white, half red, three-quarters red, red-mature and dark-red).

\section{Preparation of fruit puree}

Strawberries were homogenized at high speed in a professional blender (Kenwood Professional, Dublin, Ireland) for approximately $30 \mathrm{~s}$. The endogenous enzymes were inactivated by adding $50 \mathrm{~g}$ of a saturated ammonium sulfate (purum, Fluka AG, Buchs, Switzerland) solution to $50 \mathrm{~g}$ of fruit directly into the blender. Finally 2methyl-1-pentanol (1 mg/100 g of puree, Fluka, purum) was added as internal standard. The puree was directly used for instrumental analysis.

Instrumental analyses

Determination of total volatile compounds. Total volatile compounds of strawberries were analysed as described by Azodanlou et al. [11]. The determinations on fresh intact strawberries $(400 \pm 1 \mathrm{~g})$ were carried out in a 21 headspace flask. For the measurements on puree, $100 \pm 1 \mathrm{~g}$ of the homogenate was spread out into a crystallizing dish $(10 \mathrm{~cm}$ diameter, $3 \mathrm{~cm}$ high), which was placed in the headspace flask [11].

Quantification and identification of volatile compounds in strawberries. The concentration of the volatile compounds present in strawberries was quantified by GC-FID. The volatiles present in the headspace $(250 \mathrm{ml})$ were analysed using the procedure described in [11]. Extraction was performed using the carboxene (CAR)/ polydimethylsiloxane (PDMS) SPME fibre (Supelco Co., Bellefonte, USA). The volatile components were identified using reference compounds, Kovats retention indices data and GC-MS library data [11].

Determination of total sugar and acid contents. For the determination of total sugar content (degrees Brix) and total acidity, $200 \pm 1 \mathrm{~g}$ of strawberry puree was used to ensure sample homogeneity. Total sugar content was measured by refractometry (Atago PR1, Atago, Tokyo, Japan). Total acidity was determined by titrating a $10 \pm 0.1 \mathrm{~g}$ sample to $\mathrm{pH} 8.0$ using $0.1 \mathrm{M} \mathrm{NaOH}$ in a Mettler DL25 titrator (Mettler-Toledo, Greifensee, Switzerland). The titrated volume (in millilitres) expressed directly the total acidity in grams/litre of citric acid.

Texture analysis. The firmness of strawberries $(100 \pm 1 \mathrm{~g})$ was measured with a shear test equipment (VersaTest+Advanced Forces Gauge, Memesin, Brütsch \& Rüegger, Zurich, Switzerland) fitted with a Kramer shear cell. Strawberries were divided into two equal parts prior to measurements. The fruits were sheared at a speed of $250 \mathrm{~mm} / \mathrm{min}$ at ambient temperature. The measurements were performed in triplicate.

Statistical evaluation. The Statview program (Abacus Concepts Inc., Berkeley, Calif.) was used for analysis of variance (ANOVA) Significant differences in instrumental measurements between samples were determined by protected least significant difference (PLSD) with $P \leq 0.05$. The Statbox ${ }^{\mathrm{TM}}$ program (Grimmer, Logiciels Corp., Paris, France) was used for the Pearson's correlation $(P \leq 0.05)$ and the PCA to identify the interdependence between different stages of ripeness of the fruits and the instrumental data $(P \leq 0.05)$

\section{Results and discussion}

Total sugar and total acidity

The flavour of strawberries is greatly influenced by the presence of sugars and acids. Several authors have shown the total sugar content to increase during ripening and to stimulate the formation of secondary metabolites such as anthocyanins and furanones $[12,13]$. Further, a decrease in acidity with maturity was observed, particularly for citric acid, malic acid and quinic acid, which decreased considerably $[12,14]$. In the present study the two first stages of ripeness were not analysed, because the blender could not produce a puree with green and white strawberries. In agreement with previous studies, a general increase in the total sugar content (degrees Brix) for the three strawberry varieties investigated at the more advanced stages of ripeness (Table 1) was observed. In addition, a significant decrease in total acidity (TA) during different stages of ripening was observed. The Darselect variety contained more sugar than the two other varieties.

The ratio TA/total sugar content decreased during the ripening process (Fig. 1). At the red stage TA/total sugar content ratios of $0.97,0.72$ and 0.68 were measured for the three strawberry varieties Carezza, Darselect and Marmolada, respectively. Surprisingly there was no change in this ratio for Carezza between the two most 
Table 1 Total sugar content (degree Brix) and total acidity (TA) of three strawberry varieties at different stages of ripeness. Values are means of three replicates strawberry ripening stage and analytical measurements. $1 / 2 R$ Half-red, $3 / 4 R$ three quarters-red, $R$ redmature, $D-R$ dark-red

\begin{tabular}{|c|c|c|c|c|c|c|c|c|}
\hline \multirow[t]{2}{*}{ Variety } & \multicolumn{2}{|l|}{$1 / 2 \mathrm{R}$} & \multicolumn{2}{|l|}{$3 / 4 \mathrm{R}$} & \multicolumn{2}{|l|}{$\mathrm{R}$} & \multicolumn{2}{|l|}{ D-R } \\
\hline & $\begin{array}{l}\text { TA (g citric } \\
\text { acid/1) }\end{array}$ & $\begin{array}{l}\text { Total sugar } \\
\text { content } \\
\text { ( }{ }^{\circ} \text { Brix) }\end{array}$ & $\begin{array}{l}\text { TA (g citric } \\
\text { acid/l) }\end{array}$ & $\begin{array}{l}\text { Total sugar } \\
\text { content } \\
\left({ }^{\circ} \text { Brix) }\right.\end{array}$ & $\begin{array}{l}\text { TA (g citric } \\
\text { acid/l) }\end{array}$ & $\begin{array}{l}\text { Total sugar } \\
\text { content } \\
\left({ }^{\circ} \text { Brix }\right)\end{array}$ & $\begin{array}{l}\text { TA (g citric } \\
\text { acid/l) }\end{array}$ & $\begin{array}{l}\text { Total sugar } \\
\text { content } \\
\left({ }^{\circ} \text { Brix }\right)\end{array}$ \\
\hline Carezza & $9.7 \pm 0.03$ & $7.7 \pm 0.07$ & $8.9 \pm 0.02$ & $8.3 \pm 0$ & $8.0 \pm 0.05$ & $8.2 \pm 0.07$ & $8.2 \pm 0$ & $8.4 \pm 0$ \\
\hline Darselect & $8.9 \pm 0.06$ & $7.5 \pm 0.07$ & $8.4 \pm 0.21$ & $8.4 \pm 0.07$ & $6.7 \pm 0.01$ & $9.3 \pm 0.07$ & $6.4 \pm 0.02$ & $9.3 \pm 0.07$ \\
\hline Marmolada & $7.3 \pm 0.17$ & $6.8 \pm 0.14$ & $6.5 \pm 0$ & $6.2 \pm 0.05$ & $5.7 \pm 0.02$ & $8.4 \pm 0.14$ & $4.9 \pm 0.04$ & $8.7 \pm 0$ \\
\hline
\end{tabular}

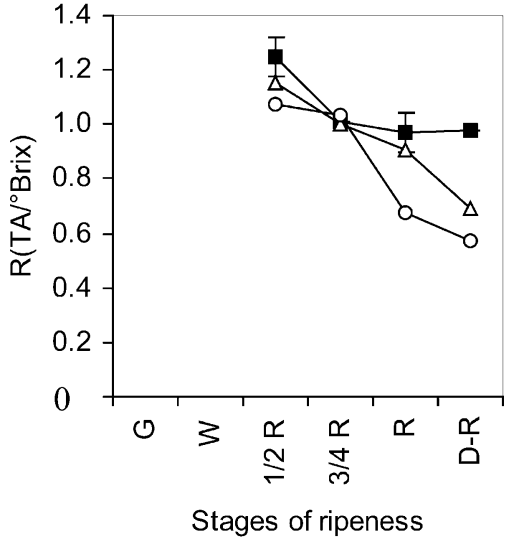

Fig. 1 Ratio of total acidity/total sugar content $\left(T A /{ }^{\circ}\right.$ Brix $)$ for Carezza (black square), Darselect (white triangle) and Marmolada (white circle) strawberries at different stages of ripeness. Stages of ripeness: $G$ green, $W$ white, $1 / 2 R$ half-red, $3 / 4 R$ three-quarters-red, $R$ red-mature, $D-R$ dark-red. Values are means of three replications

advanced stages of ripeness (red and dark-red). Further investigations are necessary to find out if this result is dependent on the variety or due to growing conditions.

Qualitative and quantitative composition of the strawberry flavour

The amount of total volatile compounds present in the headspace of strawberries adsorbed on two different SPME fibre types increased rapidly with increasing degree of ripeness of the fruits. The analyses performed with the PDMS and the CAR/PDMS fibres (Fig. 2) gave correlation values of $r=0.65-0.97$. However, using the polyacrylate fibre very weak correlations were obtained $(r=0.08-0.55)$, probably due to poor adsorption.

Thirty volatile compounds were identified and quantified in the headspace of strawberries [11]. Most of them showed a statistically significant increase in concentration during maturation (Table 2). Many of the volatile compounds described in Table 2 clearly allowed discrimination between unripe and ripe strawberries.

After sorting out non-discriminant volatile compounds, PCA was carried out to cluster ripe and unripe fruits. Of the variability, $76 \%$ could be explained by the two principal components. From Fig. 3 it can be clearly seen that the first principal component discriminated the unripe samples according to the contents of hexanal, propyl butanoate, 3-phenyl-1-propanol, butyl butanoate, isobutyl butanoate, 3-methyl butyl butanoate and isopropyl hexanoate. Hexanal was the predominant component in the chromatograms of the green fruit samples in all varieties. The concentration of green aroma components such as hexanal, trans-2-hexenol and cis-3-hexenyl acetate progressively decreased during the ripening process until they became minor components in the mature samples.

The results suggested that the ripening process in strawberries can be followed by analysing the content of specific volatile compounds. It was thus possible to characterize the degree of ripeness of the two varieties Carezza and Marmolada by their contents in 2-methyl butanoic acid and 2-methyl butyl butanoate. Ethyl 2methyl butanoate proved to be typical for the Carezza variety.

It has been reported that furaneol (2,5-dimethyl-4hydroxy-furane) is the most important component for the strawberry aroma [9, 15]. Our results indicated the furaneol concentration to be quite fluctuating throughout the ripening process, probably due to its metabolism. It is in fact known that this compound is not very stable [8].

According to Table 2 the flavour components of strawberries belong predominantly to the chemical classes of esters, aldehydes, alcohols, acids and furans. It was interesting to note that the sum of the esters increased considerably during the last stages of ripening (Fig. 4). Butyl acetate and ethyl butanoate seem to play an important role. Their concentrations correlated well with the overall appreciation expressed by consumers [11].

\section{Texture analysis}

The firmness of the strawberries as measured by the Kramer's shear cell decreased dramatically during the ripening process (Fig. 5). At the ripening stage red-mature (R) the maximal force for the varieties Carezza, Darselect, and Marmolada were $167 \mathrm{~N}, 200 \mathrm{~N}$ and $330 \mathrm{~N}$, respectively. Strawberry softening is a consequence of changes in physical and mechanical properties of the tissue based on changes in the chemical structure of the cell wall polysaccharides (cellulose, hemicelluloses and pectins). It was shown that pectins play a key role in fruit 
Table 2 Identification and quantification of volatile compounds in the strawberry varieties Carezza, Darselect and Marmolada by GCMS and GC-FID, after SPME with the CAR/PDMS fibre. Values given in the column unripe represent the average of the degrees of ripeness green, white and half to red. The variation between the different measurements did not exceed $\pm 5 \%$. Values given in the column ripe represent the average of the degrees of ripeness $3 / 4$ to red, red, and dark-red

\begin{tabular}{|c|c|c|c|c|c|c|c|c|c|}
\hline & \multirow[t]{2}{*}{ Volatile compound } & \multirow{2}{*}{$\begin{array}{l}\text { Odour threshold } \\
(\mathrm{mg} / \mathrm{kg})\end{array}$} & \multirow[t]{2}{*}{ Odour } & \multicolumn{6}{|c|}{ Concentration $(\mathrm{mg} / \mathrm{kg})$} \\
\hline & & & & Unripe & $\overline{\text { Ripe }}$ & Unripe & $\overline{\text { Ripe }}$ & Unripe & Ripe \\
\hline$\overline{\text { Esters }}$ & $\begin{array}{l}\text { Butyl acetate } \\
\text { Isoamyl acetate } \\
\text { Hexyl acetate } \\
\text { cis-3-Hexenyl acetate } \\
\text { Bornyl acetate } \\
\text { Methyl butanoate } \\
\text { Methyl-2-methylbutanote } \\
\text { Ethyl butanoate } \\
\text { Propyl butanoate } \\
\text { Isopropyl butanoate } \\
\text { Ethyl-2-methylbutanoate } \\
\text { Butyl butanoate } \\
\text { Isobutyl butanoate } \\
\text { 2-Methylbutyl butanoate } \\
\text { 3-Methylbutyl butanoate } \\
\text { Hexyl butanoate } \\
\text { Methyl hexanoate } \\
\text { Ethyl hexanoate } \\
\text { Isopropyl hexanoate } \\
\text { Hexyl hexanoate }\end{array}$ & $\begin{array}{l}10^{-2} \text { to } 10^{-1 \mathrm{c}} \\
10^{-2} \text { to } 10^{-1 \mathrm{c}}\end{array}$ & $\begin{array}{l}\text { Apple, glue } \\
\text { Banana }^{\mathrm{d}} \\
\text { Banana, apple, }_{\text {pear }^{\mathrm{c}}} \\
\text { Green banana }^{\mathrm{d}} \\
\text { Fruity, cheese }^{\mathrm{c}} \\
\text { Sweet } \\
\text { Fruity, sweet, }_{\text {cheese }^{\mathrm{c}}} \\
\text { Pineapple }^{\mathrm{d}} \\
\text { Pungent }^{\mathrm{d}}\end{array}$ & $\begin{array}{l}0.00^{\mathrm{a}} \\
0.03^{\mathrm{a}} \\
1.03^{\mathrm{a}} \\
4.29^{\mathrm{a}} \\
0.04^{\mathrm{a}} \\
0.23^{\mathrm{a}} \\
0.00^{\mathrm{a}} \\
0.00^{\mathrm{a}} \\
0.00^{\mathrm{a}} \\
0.00^{\mathrm{a}} \\
0.31^{\mathrm{a}} \\
0.35^{\mathrm{a}} \\
0.00^{\mathrm{a}} \\
0.00^{\mathrm{a}} \\
0.00^{\mathrm{a}} \\
0.30^{\mathrm{a}} \\
0.00^{\mathrm{a}} \\
1.09^{\mathrm{a}} \\
0.00^{\mathrm{a}} \\
0.45^{\mathrm{a}}\end{array}$ & $\begin{array}{l}1.67^{\mathrm{b}} \\
0.54^{\mathrm{b}} \\
8.11^{\mathrm{b}} \\
1.72^{\mathrm{a}} \\
0.16^{\mathrm{a}} \\
4.75^{\mathrm{b}} \\
0.17^{\mathrm{b}} \\
2.87^{\mathrm{b}} \\
0.08^{\mathrm{b}} \\
0.92^{\mathrm{b}} \\
0.39^{\mathrm{a}} \\
2.65^{\mathrm{b}} \\
2.69^{\mathrm{b}} \\
0.08^{\mathrm{b}} \\
0.27^{\mathrm{b}} \\
1.13^{\mathrm{a}} \\
3.12^{\mathrm{b}} \\
5.25^{\mathrm{b}} \\
0.40^{\mathrm{b}} \\
0.53^{\mathrm{a}}\end{array}$ & $\begin{array}{l}0.00^{\mathrm{a}} \\
0.00^{\mathrm{a}} \\
0.09^{\mathrm{a}} \\
5.43^{\mathrm{a}} \\
0.07^{\mathrm{a}} \\
0.00^{\mathrm{a}} \\
0.00^{\mathrm{a}} \\
0.00^{\mathrm{a}} \\
0.00^{\mathrm{a}} \\
0.00^{\mathrm{a}} \\
0.00^{\mathrm{a}} \\
0.21^{\mathrm{a}} \\
0.15^{\mathrm{a}} \\
0.00^{\mathrm{a}} \\
0.00^{\mathrm{a}} \\
0.23^{\mathrm{a}} \\
0.00^{\mathrm{a}} \\
0.25^{\mathrm{a}} \\
0.00^{\mathrm{a}} \\
0.36^{\mathrm{a}}\end{array}$ & $\begin{array}{l}1.25^{\mathrm{b}} \\
0.19^{\mathrm{a}} \\
0.96^{\mathrm{b}} \\
0.26^{\mathrm{b}} \\
1.58^{\mathrm{b}} \\
{ }^{0.06^{\mathrm{b}}} \\
0.13^{\mathrm{b}} \\
0.00^{\mathrm{a}} \\
3.36^{\mathrm{b}} \\
2.69^{\mathrm{b}} \\
0.00^{\mathrm{a}} \\
0.13^{\mathrm{b}} \\
2.83^{\mathrm{b}} \\
9.02^{\mathrm{b}} \\
2.55^{\mathrm{b}} \\
0.19^{\mathrm{b}} \\
0.55^{\mathrm{a}}\end{array}$ & $\begin{array}{l}0.00^{\mathrm{a}} \\
0.00^{\mathrm{a}} \\
0.27^{\mathrm{a}} \\
3.78^{\mathrm{a}} \\
0.19^{\mathrm{a}} \\
0.16^{\mathrm{a}} \\
0.00^{\mathrm{a}} \\
0.00^{\mathrm{a}} \\
0.00^{\mathrm{a}} \\
0.00^{\mathrm{a}} \\
0.00^{\mathrm{a}} \\
0.05^{\mathrm{a}} \\
0.00^{\mathrm{a}} \\
0.00^{\mathrm{a}} \\
0.00^{\mathrm{a}} \\
0.33^{\mathrm{a}} \\
0.11^{\mathrm{a}} \\
0.20^{\mathrm{a}} \\
0.00^{\mathrm{a}} \\
0.11^{\mathrm{b}}\end{array}$ & $\begin{array}{l}0.85^{\mathrm{b}} \\
0.14^{\mathrm{b}} \\
4.10^{\mathrm{b}} \\
\\
2.10^{\mathrm{a}} \\
0.59^{\mathrm{b}} \\
5.96^{\mathrm{b}} \\
0.47^{\mathrm{b}} \\
3.29^{\mathrm{b}} \\
\\
0.10^{\mathrm{b}} \\
0.80^{\mathrm{b}} \\
0.00^{\mathrm{a}} \\
3.33^{\mathrm{b}} \\
4.56^{\mathrm{b}} \\
0.23^{\mathrm{b}} \\
0.66^{\mathrm{b}} \\
1.95^{\mathrm{b}} \\
4.58^{\mathrm{b}} \\
2.90^{\mathrm{b}} \\
0.47^{\mathrm{b}} \\
0.224^{\mathrm{b}}\end{array}$ \\
\hline Aldehydes & $\begin{array}{l}\text { Hexanal } \\
\text { trans-2-Hexenal } \\
\text { trans-2-Hexenal }\end{array}$ & $\begin{array}{l}10^{-2} \text { to } 10^{-1 \mathrm{c}} \\
0.17^{\mathrm{d}} \\
0.17^{\mathrm{d}}\end{array}$ & $\begin{array}{l}\text { Green, sourc } \\
\text { Fatty }^{\mathrm{d}} \\
\text { Fatty }^{\mathrm{d}}\end{array}$ & $\begin{array}{l}0.63^{\mathrm{a}} \\
0.04^{\mathrm{a}} \\
0.04^{\mathrm{a}}\end{array}$ & $\begin{array}{l}0.00^{\mathrm{b}} \\
1.01^{\mathrm{b}} \\
1.01^{\mathrm{b}}\end{array}$ & $\begin{array}{l}0.54^{\mathrm{a}} \\
0.22^{\mathrm{a}} \\
0.22^{\mathrm{a}}\end{array}$ & $\begin{array}{l}0.16^{\mathrm{b}} \\
0.00^{\mathrm{b}} \\
0.00^{\mathrm{b}}\end{array}$ & $\begin{array}{l}0.65^{\mathrm{a}} \\
0.00^{\mathrm{a}} \\
0.00^{\mathrm{a}}\end{array}$ & $\begin{array}{l}0.29^{b} \\
0.20^{b} \\
0.20^{b}\end{array}$ \\
\hline Alcohols & $\begin{array}{l}\text { trans-2-Hexenol } \\
\text { 1-Octanol } \\
\text { Linalool } \\
\text { 3-Phenyl-1-propanol }\end{array}$ & $10^{-4}$ to $10^{-3 c}$ & $\begin{array}{l}\text { Green, fruity, } \\
\text { burnt }^{\mathrm{c}} \\
\text { Chemical }^{\mathrm{d}} \\
\text { Lemon peel, } \\
\text { flowers }^{\mathrm{c}}\end{array}$ & $\begin{array}{l}2.25^{\mathrm{a}} \\
0.00^{\mathrm{a}} \\
0.18^{\mathrm{a}} \\
0.00^{\mathrm{a}}\end{array}$ & $\begin{array}{l}0.20^{\mathrm{b}} \\
0.00^{\mathrm{a}} \\
1.56^{\mathrm{b}} \\
0.10^{\mathrm{b}}\end{array}$ & $\begin{array}{l}0.78^{\mathrm{a}} \\
0.00^{\mathrm{a}} \\
0.09^{\mathrm{a}} \\
0.00^{\mathrm{a}}\end{array}$ & $\begin{array}{l}0.00^{\mathrm{b}} \\
0.00^{\mathrm{a}} \\
1.81^{\mathrm{b}} \\
0.10^{\mathrm{b}}\end{array}$ & $\begin{array}{l}0.56^{\mathrm{a}} \\
0.00^{\mathrm{a}} \\
0.07^{\mathrm{a}} \\
0.00^{\mathrm{a}}\end{array}$ & $\begin{array}{l}0.29^{\mathrm{a}} \\
0.12^{\mathrm{b}} \\
1.07^{\mathrm{b}} \\
0.18^{\mathrm{b}}\end{array}$ \\
\hline
\end{tabular}

${ }_{\mathrm{a}, \mathrm{b}}$ Values which are marked by different letter are significantly different based on the protected least significant difference test at $P \leq 0.05$ c [18]

d $[19]$

Fig. 2a, b Amounts of total volatile compounds of Carezza (black square), Darselect (white triangle) and Marmolada (white circle) strawberries at different stages of ripeness. a PDMS fibre. $\mathbf{b}$ carboxene/polydimethylsiloxane fibre. Stages of ripeness: $\mathrm{G}$ green, $\mathrm{W}$ white, 1/2 R half-red, 3/4 R threequarters-red, $\mathrm{R}$ red-mature, D-R dark-red. Values are means of three replications

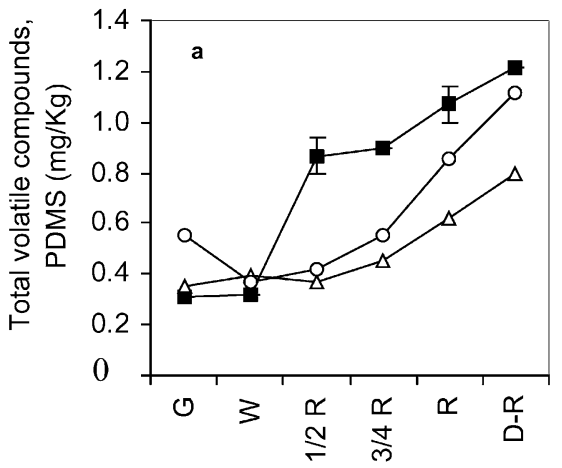

Stages of ripeness

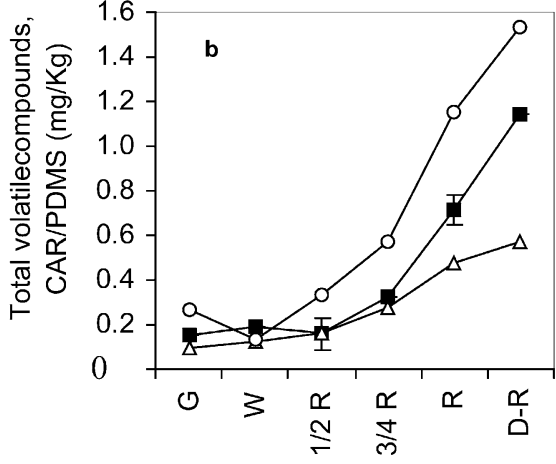

Stages of ripeness 
Fig. 3 Principal components of the strawberry varieties Carezza $(C)$, Darselect $(D)$ and Marmolada $(M)$. Twenty-four variables were evaluated. $x$ Volatile components, black squares stages of ripeness $(\mathrm{G}$ green, $\mathrm{W}$ white, $1 / 2 \mathrm{R}$ half-red, $3 / 4 \mathrm{R}$ three-quarters-red, $\mathrm{R}$ red-mature, D-R dark-red)

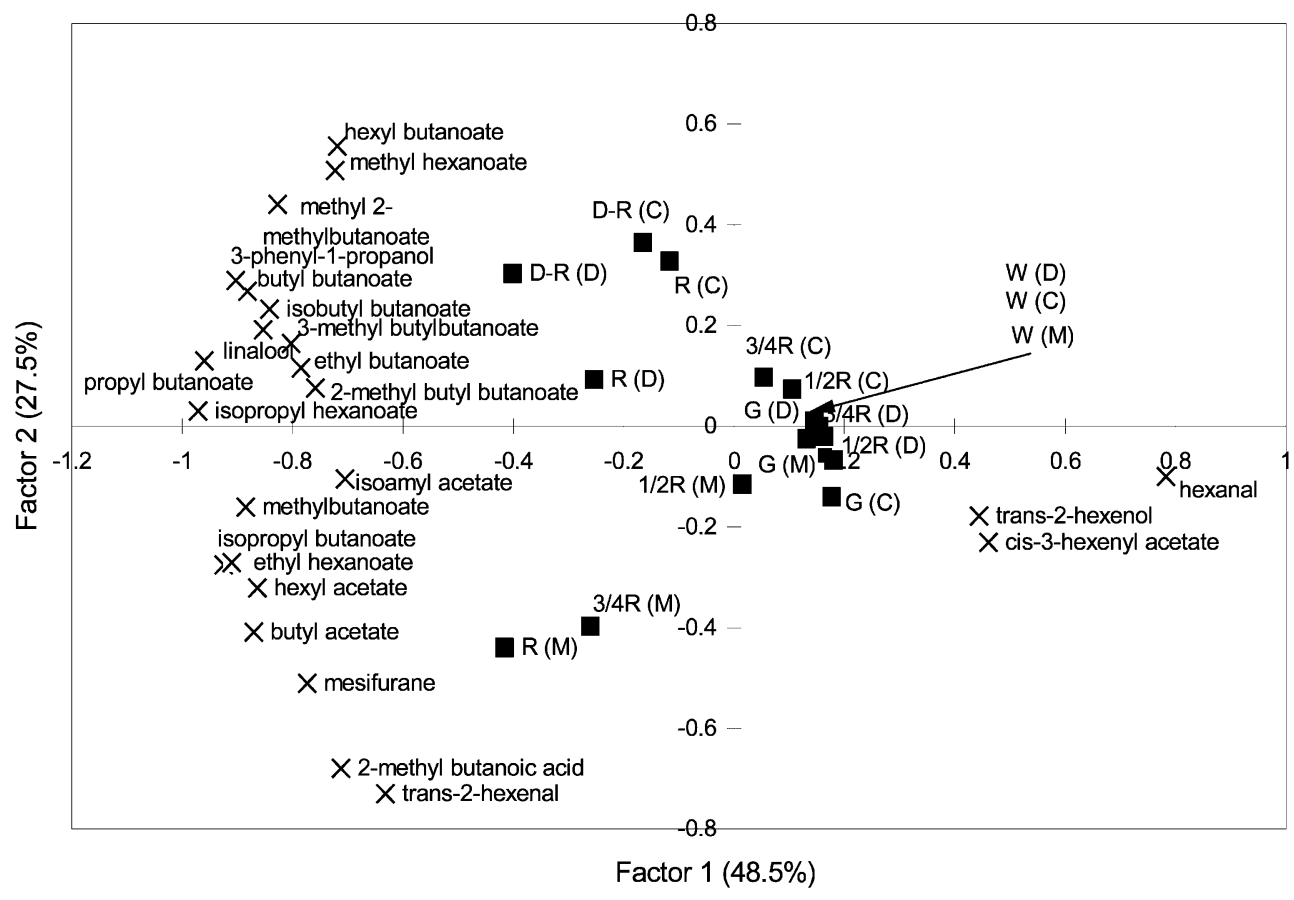

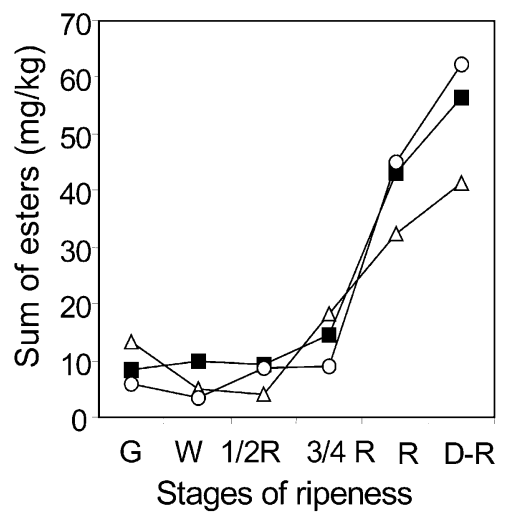

Fig. 4 Sum of volatile esters in Carezza (black square), Darselect (white triangle) and Marmolada (white circle) strawberries at different stages of ripeness. Stages of ripeness: G green, $W$ white, $1 / 2 \mathrm{R}$ half-red, 3/4 $\mathrm{R}$ three-quarters-red, $\mathrm{R}$ red-mature, $\mathrm{D}-\mathrm{R}$ darkred. Values are means of three replications

softening, since they are partially solubilized by endogenous pectin-degrading enzymes (polygalacturonases and pectin methyl esterases) during ripening, leading to tissue softening [16].

In conclusion, the quantitative determination of total volatile compounds in the headspace [17] has been shown to be a powerful tool for the characterization of the ripeness of strawberries. The use of PCA turned out to be very useful in visualizing the correlations between different strawberry varieties (Carezza, Darselect and Marmolada). Important volatile components and classes of compounds were identified by GC-FID and GC-MS. It was possible to correlate some of the individual components to the stages of ripeness. Esters represent key aroma

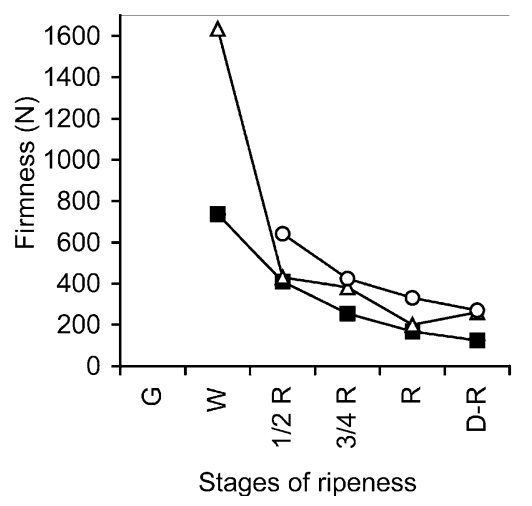

Fig. 5 Firmness $\left(F_{\max }\right.$ in $\left.\mathrm{N}\right)$ of the strawberry varieties Carezza (black square), Darselect (white triangle) and Marmolada (white circle) at different stages of ripeness. Stages of ripeness: $G$ green, W white, 1/2 R half-red, 3/4 R three-quarters-red, R red-mature, D$\mathrm{R}$ dark-red. Values are means of three replications

components in strawberries. Their total amount increased during ripening.

Acknowledgements The authors thank the Swiss Federal Office for Science and Education and the Canton of Valais for their financial support of this project which was carried out in the frame of the COST 915 action "Improvement of quality of fruit and vegetables, according to the needs of the consumers".

\section{References}

1. Dirinck P, De Pooter H, Schamp N (1989) Aroma development in ripening fruits. In: Teranishi R, Butterey RG, Shahidi F (eds) Flavor chemistry: trends and developments. ACS, Washington DC, pp 23-34

2. Abeles FB, Takeda F (1990) Sci Hortic Amsterdam 42:269-275 
3. Mitchell WC, Jelenkovic G (1995) J Am Soc Hortic Sci 120:798-801

4. Makinen KK, Séderling E (1980) J Food Sci 45:37-371

5. Coultate TP (1996) Food. In: Coultate, TP (ed) Food: the chemistry of its components. Royal Society of Chemistry, Cambridge, pp 169-207

6. Yamashita I, Iino K, Nemoto Y, Yoshikawa S (1977) J Agric Food Chem 25:1165-1168

7. Ito O, Sakakibara H, Yajima I, Hayashi K (1990) Flavour Sci Technol Weurman Symp 6th, pp 69-72

8. Pérez AG, Rios JJ, Sanz C, Olías JM (1992) J Agric Food Chem 40:2232-2235

9. Sanz C, Richardson DG, Pérez AG (1995) 2,5-Dimethyl-4hydroxy-3 $2 \mathrm{H}$ ) furanone and derivatives in strawberries during ripening. ACS, Symp Ser 1995, 268-275

10. Parliment TH (1997) Solid-phase extraction for the analysis of flavors. In: Marsili R (ed) Techniques for analyzing, food aroma. Dekker, New York, pp 81-112
11. Azodanlou R, Darbellay C, Luisier JL, Villettaz JC, Amadò R (2003) J Agric Food Chem 51:715-721

12. Woodward JR (1972) J Sci Food Agric 23:465-473

13. Pisarnitskii AF, Demechenko AG, Egorov IA, Gvelesiani RK (1992) Appl Biochem Microbiol 28:97-100

14. Sistrunk WA, Cash JN (1973) J Food Sci 38:807-809

15. Ulrich D, Rapp A, Hoberg E (1995) Z Lebensm Unters Forsch 200:217-220

16. Fischer RL, Bennett AB (1991) Annu Rev Plant Physiol 42:675-703

17. Azodanlou R, Darbellay C, Luisier JL, Villettaz JC, Amadò R (1999) Z Lebensm Unters Forsch A 208:254-258

18. Larsen M, Poll L, Olsen CE (1992) Z Lebensm Unters Forsch 195:536-539

19. http://www.nysaes.cornell.edu/flavornet/chem.html. Cornell University, Ithaca, USA 